\title{
Keeping Rights Alive: Reform and Reconciliation in Post-War Sri Lanka
}

\author{
Mario Gomez ${ }^{1}$
}

\section{INTRODUCTION}

\section{a. The End of the War}

The war in Sri Lanka came to a sudden end in May 2009 when the Sri Lankan military defeated the Liberation Tigers of Tamil Eelam (LTTE) and eliminated its senior leadership. The United Nations (U.N.), international organizations and domestic organizations alleged that thousands of civilians died in the final phases of the war. ${ }^{2}$ These claims were strenuously denied by the government and the military. Till now there has been no accounting process of the final stages of the war.

In January 2010, the President called an election two years before the end of his term and won a landslide victory. His victory at the election was fuelled to a large extent by his government's victory over the LTTE. In April 2010, a Parliamentary election was held in which the ruling United People's Freedom Alliance (UPFA) coalition won convincingly and came close to securing a two thirds majority in Parliament.

Many other societies that transited from war to peace or dictatorship to democracy were forced to negotiate political compromises, establish new institutions and constitutions, and in some cases, probe the past. However, not in Sri Lanka. The government's decisive victory over the LTTE has

1 Executive Director, International Centre for Ethnic Studies (ICES) and Visiting Lecturer, University of Colombo.

2 See U.S. Dep't of State, Report to Congress on Incidents During the Recent Conflict in Sri lanka (2009); Int'l Crisis Grp., War Crimes in Sri Lanka, Asia Report No. 191 (2010). 
enabled it to ignore the issues that gave rise to the violence and focus on securing a political future for the regime. ${ }^{3}$

Sri Lanka is a much safer place to live in than it was three years ago. The horrific violence that destroyed lives, property, relationships, childhoods, aspirations and social life is a thing in the past, at least for the moment. The insecurities and fear that the violence generated have been extinguished.

Yet the unwillingness of the state to address long standing and deep rooted social and political issues is slowly generating a new set of fears and insecurities. Despite the rhetoric, little has occurred since the end of the war to suggest that reconciliation, constitutional reform or the rule of law are priorities for the government. Rather, the only constitutional amendment that was passed has strengthened the power of an already powerful President, made it possible for him to contest a third term and undermined the credibility of the country's independent institutions. Postwar reconstruction and rebuilding has been tightly controlled with little consultation with stakeholders. Impunity, which has been a problem for over thirty years, has not been addressed. Accompanying this has been an unprecedented crackdown on dissent and the media, sometimes resulting in the death or disappearance of the dissenter. ${ }^{4}$

See the statement of the "The Elders" in 2010. The Elders consist of Martti Ahtisaari, Kofi Annan, Ela Bhatt, Lakhdar Brahimi, Gro Brundtland, Fernando Henrique Cardoso, Jimmy Carter, Graça Machel, Mary Robinson and Desmond Tutu (Chair). Nelson Mandela and Aung San Suu Kyi are honorary Elders. See Press Release, Sri Lanka’s Disturbing Actions Met by 'Deafening Global Silence' (Aug. 3, 2010), http://theelders.org/article/sri-lankas-disturbing-actions-met-deafening-globalsilence.

4 See Int'l Bar Ass'n, Justice in Retreat: A Report on the Independence of the Legal Profession and the Rule of Law in Sri Lanka 57 (2009). According to Journalists for Democracy, the number of journalists killed between 2004 and August 2009 was 34, and according to the News Safety Institute more than 50 journalists have left the country. See Transparency INT'L SRI LANKA, SRI LANKa: GovernanCe Report 200950 (2009), available at http:// www.tisrilanka.org/pub/pb/pdf/sgr2009.pdf; InT'L Fed’N OF Journalists, KeY Challenges for Media after War's End: Report of the International Press Freedom Mission to Sri LANKa (2010), available at http://www.ifj.org/ assets/docs/236/115/1d464ec-8892c73.pdf. See also http://www.i-m-s.dk/files/ publications/Key\%20challenges\%20for\%20media\%20after\%20war\%27s\%20end- 


\section{b. The Last Phase of the War}

Few would have predicted such a rapid end of the war in Sri Lanka. The last phase of the war commenced in 2006 soon after the LTTE attempted to assassinate the Army Commander and the Defense Secretary, both of which did not succeed. As late as February 2009, the LTTE sent two light aircrafts into the city of Colombo in a sortie that caused considerable panic. By the middle of May that year, however, the war was over and one of Asia's longest civil wars had come to an abrupt end. Fighting alongside the government forces were a breakaway faction of the LTTE and other Tamil groups that had previously fought against the Sri Lankan state. ${ }^{5}$

U.N. officials estimated that about 7,500 were killed and about 15,000 were wounded between January and early May 2009 when the LTTE and the government fought the final battles. ${ }^{6}$ Many more are thought to have died between early May and May $19^{\text {th }}$ when the government announced the elimination of most of the LTTE leadership. ${ }^{7}$ The International Crisis Group (ICG) estimates that "tens of thousands" died in the last phase of the war. ${ }^{8}$ According to the ICG, there were frequent violations of international humanitarian law by both the government and LTTE in the five months leading to the end of the war. ${ }^{9}$

According to the ICG, there is credible evidence that the armed forces repeatedly shelled civilians in "No Fire Zones" declared by the government, shelled hospitals and makeshift medical facilities, and shelled humanitarian operations and food distribution points. The report also charges the LTTE with shooting civilians who attempted to flee into government controlled

IFJ\%20Mission\%20report-dec09-ENG.pdf.

5 For a "ringside" account of the last phase of the war, see Gordon Weiss, The Cage: The Fight for Sri Lanka And the Last Days of the Tamil Tigers (2011).

6 INT'L CRISIS GRP., supra note 2, at 5.

$7 \quad$ Id. at $1-2$.

$8 \quad I d$. at 5.

9 Id. 
areas and forcibly keeping civilians against their will despite the threats to their lives and the lack of food and other basic supplies. ${ }^{10}$

The U.S. Department of State in its report lists several hundred incidents which it stated may a mount to violations of international humanitarian or human rights law or constitute crimes against humanity committed by both the armed forces and the LTTE. ${ }^{11}$

The government appointed Lessons Learnt and Reconciliation Commission (LLRC) concluded that the armed forces did not deliberately target the civilians during the large stages of the war. It recommended, however, that specific events including the shelling of hospitals and "No Fire Zones" be investigated further. ${ }^{12}$

\section{c. Background to the Conflict}

Sri Lanka consists of seven major population groups: Sinhalese - mainly Buddhist, but also Christian; Tamils - mainly Hindu, but also Christian; Muslims; Tamils of Recent Indian Origin - who were brought from India to work the tea plantations and who live mainly in the Central part of the country; Burghers - descendants of the Dutch, Portuguese and British who inter-married; Malays - Muslims who were part of a migration from South East Asia; and other smaller groups of minorities.

Charges of discrimination have been hurled from different groups. The Sinhalese contended that the Tamils wielded a disproportionate amount of public power when Sri Lanka was known as Ceylon and a British colony. It was argued by the Sinhalese that this was a part of a deliberate policy on the part of the British to "divide and rule." A consequence of this policy was a disproportionate number of public service appointments that was held by the Tamils, at the time of independence. It is also alleged that educational and other facilities in the Northern Province, which is almost 90 percent

$10 \quad I d$.

11 U.S. Dep't of State, supra note 2.

12 Lessons Learnt and Reconciliation Comm'n, Report of the Commission OF INQUiRy ON LESSONS LEARNT AND RECONCILIATION (2011) [hereinafter LLRC Report], on file with the author. See below for a fuller discussion of the LLRC Report. 
Tamil, were at a better stage of development than other predominantly Sinhalese areas at that time.

From the Tamil's come allegations that there has been a consistent policy of discrimination by Sinhalese dominated governments since independence. Few government resources have been channeled into areas where Tamils reside, and they have been discriminated against with regard to the use of the Tamil language, educational opportunities, and access to public service jobs. ${ }^{13}$

\section{VIOLENCE BY SINHALA GROUPS}

Sri Lanka has experienced a number of bouts of political violence over the past 40 years. In 1971, the JanathaVimukthi Peramuna (People's Liberation Front) or JVP sought to capture state power through a violent struggle that was crushed ruthlessly by the government at that time. ${ }^{14}$

In 1987, the JVP staged a comeback. During a two year period they brought the country to a halt through a series of tactics that entailed intimidation and fear. The violence came to an end in November 1989 when most of the leadership was killed. Some escaped, returned to Sri Lanka and formed a mainstream political party which is now represented in Parliament.

\section{VIOLENCE BY TAMIL GROUPS}

In 1976, a Tamil political party adopted the "Vaddukoddai Resolution" which called for the creation of "a free, sovereign, secular, socialist state of Tamil Eelam" based on the right of self-determination inherent to every

13 See John Richardson, Paradise Poisoned: Learning about Conflict, Terrorism and Development from Sri Lanka's Civil Wars-(2005); R. Hoole et al., The Broken Palmyra, the Tamil Crisis in Sri Lanka, an Inside Account (1992); K. M. de Silva, Reaping the Whirlwind: Ethnic Conflict, Ethnic Politics in Sri Lanka (2000); M. R. Narayan Swamy, Tigers of Lanka: From Boys to Guerrillas (2006) (1994).

14 H.A.I. Goonetileke, The April 1971 Insurrection in Ceylon: A Bibliographical Commentary (2d ed. 1975). 
nation. The resolution argued that the Tamils had tried to live together with Sinhalese but this was now not possible.

The Vaddukodai Resolution marked the commencement of a struggle for the establishment of a separate state of Tamil Eelam. While there had been many demands for Tamil's independence before, this Resolution articulated for the very first time, in very clear terms, the demand for an independent state for the Tamil Nation based on their historical habitation in the Northern and Eastern provinces. ${ }^{15}$

The Resolution came four years after the adoption of the 1972 Constitution. The 1972 Constitution made Sri Lanka a unitary state for the first time, gave "foremost" place to Buddhism, and made Sinhala the official language. It also expressly precluded the courts from reviewing the constitutional validity of legislation and removed an important safeguard for minorities that was in the previous constitution. At around this time, language based "standardization" with regard to entry to Sri Lankan universities had angered Tamil youth. The Vaddukodai Resolution and the 1972 Constitution are turning points in Sri Lankan politics. They resulted in the marginalization of moderate forces and the emergence of the radical forces among the Tamils of Sri Lanka.

Tamil groups began to embrace violence in the mid-1970s. Over a period of time the LTTE emerged as the strongest group. In 1983, thirteen army soldiers were killed by the LTTE in Jaffna and soon after ethnic riots erupted in Colombo. Many Tamils were killed and many lost property. Many left for overseas with disgust and anger. There was substantial evidence to show that the state was involved in fuelling the riots or at the very least "standing by" while the rioting and looting took place. ${ }^{16}$

Since then, the war was fought brutally by both the government and LTTE. Both sides have attacked not only military targets but also civilians and their property, and other places including temples and places of historical and intellectual value. Over the years, the U.N. Special Procedures

15 The Vaddukodai Resolution was adopted by the Tamil United Liberation Front (TULF) at its First National Convention. It was held at Vaddukoddai on May 14, 1976 under the chair of S.J.V. Chelvanayakam.

16 Paul Sieghart, Sri lanka: A Mounting Tragedy of Errors: Report of a Mission on Sri Lanka in January 1984 on behalf of the International Commission of Jurists And its British Section, Justice (1984). 
and human rights groups have documented thousands of human rights violations by both the state and non-state actors.

The Muslims, many of whom have lived for years in the North and East, have suffered particularly. In 1990, about 70,000 Muslims were evicted overnight from the North by the LTTE and many have still not been able to return. During the conflict, Muslims villages were attacked and Muslim villagers were butchered by the LTTE who accused Muslims for collaborating with Sri Lankan armed forces. Both Muslims and Tamils share the same language. ${ }^{17}$

In January 2003, a group of students led by the student body of the South Eastern University adopted the Oluvil Declaration at a mass political rally held in Oluvil in the Ampara District of the Eastern Province. The Oluvil Declaration argued that the Muslims of the North East are a separate nationality and nation with a distinct identity, religion and culture. It noted that the North East is the traditional homeland of the Muslims and called for an autonomous, self-governing political unit linking all Muslim majority areas of the north and east (Muslim Thesam).

Tamil groups had previously presented similar ideas in what is commonly known as the "Thimpu Principles" and the Oluvil Declaration is in some respect a response to the "Thimpu Principles."At the Peace Talks held in Thimpu, Bhutan in July 1985 six Tamil groups presented four cardinal principals which they said should shape any solution to the ethnic conflict:

1. Recognition of the Tamils of Sri Lanka as a distinct nationality.

2. Recognition of an identified Tamil homeland and the guarantee of its territorial integrity.

3. Based on the above, recognition of the inalienable right of selfdetermination of the Tamil nation.

17 The Quest for Redemption: The Story of the Northern Muslims: Final Report of the Citizens' Commission on the Expulsion of Muslims from the Northern Province by the LTTE in October 1990 (2011). 
4. Recognition of the right to full citizenship and other fundamental democratic rights of all Tamils who look upon the island as their country. ${ }^{18}$

In the 1980s, there was support for the militant Tamil groups from India and many of the armed groups received secret military training supported by the Research and Analysis Wing (RAW). Indian support for the LTTE began to wane when a LTTE suicide bomber killed Prime Minister Rajiv Gandhi in the 1990s.

In 1987, the Indian government persuaded the government of Sri Lanka and the LTTE to sign a peace accord and agree to a quasi-federal state. Although the Sri Lankan government introduced the $13^{\text {th }}$ and $16^{\text {th }}$ Amendments to the Constitution and introduced a quasi-federal structure, the agreement collapsed and the war resumed. ${ }^{19}$

For many years, the LTTE had been in control of a portion of the North East of the country, mainly in the Jaffna, Mannar, Killinochchi, Mullativu and Vavuniya districts. In those regions, it established rudimentary state structures, including its own police force and a courts system. In LTTE controlled areas, both free movement and free expression were subject to restrictions and any form of dissent tightly controlled. ${ }^{20}$

A new phase in the conflict commenced in 2006. After the LTTE launched a series of claymore mine attacks and attempted to kill the Army Commander and the Secretary Defense in suicide attacks, government

18 Statement made by a delegation of Tamil groups consisting of PLOTE, EPRLF, EROS, LTTE, TELO, and the TULF at the peace talks between the Government of Sri Lanka and Tamil groups held in Thimpu, Bhutan, July 1985. See TAmiL United Liberation Front Towards Devolution of Power in Sri Lanka: Main Documents August 1983 to OCtober 1987 (1988), also commonly known as the “Thimpu Principles." See also Ketheshwaran Loganathan, Sri Lanka: Lost Opportunities: Past Attempts at Resolving Ethnic Conflicts (1996).

19 India-Sri Lanka: Agreement to Establish Peace and Normalcy in Sri Lanka, 26 American International Legal Materials 1175 (1987), available at http:// www.jstor.org/stable/20693151. See Keethaponcalan S. I., Conflict and Peace in Sri Lanka: Major Documents: With an Introductory Note on Each DOCUMENT 104 (2009).

20 See Jayadeva Uyangoda, Ethnic Conflict in Sri Lanka: Changing Dynamics (Muthiah Alagappa ed. 2007). 
forces launched a sustained military campaign to eliminate the LTTE. This culminated in the defeat of the LTTE as a military force in May 2009.

\section{d. The 2002-2003 Peace Process}

There have been many attempts to negotiate peace in Sri Lanka, the most serious of which was in 2002-2003. The United National Front government was elected to power in December 2001 and the LTTE declared a unilateral ceasefire on the Christmas Eve of that year. The government responded and the two parties signed a Norwegian-brokered Ceasefire Agreement in February 2002. ${ }^{21} \mathrm{After}$ a year of unexpected progress and six rounds of talks in Thailand, Norway, Japan and Germany, the process stopped as suddenly as it started.

The Ceasefire Agreement of 2002 was based on an acceptance of the then-military balance of power, which meant an acceptance by the Sri Lankan State that the LTTE controlled certain areas of territory and the recognition of those forward defence lines and an equal parity of status for the LTTE. The Ceasefire Agreement also emphasised the urgency of restoring a sense of normalcy in the North of the country and an opening of the only land route - the A9 highway - between the North and South. It ensured that Norway would continue as a mediator and establish the Sri Lanka Monitoring Mission (SLMM), consisting of Scandinavian monitors led by Norway and local monitoring teams to monitor the ceasefire. ${ }^{22}$

\section{e. The Tsunami of 2004}

The tsunami in December 26, 2004 killed over 30,000 people and destroyed livelihoods and property on an unprecedented scale. It devastated coastlines on the North, East, South and West coasts of Sri Lanka and shattered the hopes and aspirations of people from all communities. Many of those who suffered from the tsunami had already suffered as a result of the conflict. While the scale of the tsunami was unprecedented, the wave of human solidarity it generated was similarly unparalleled. It mobilised Sri Lankans and non-Sri Lankans, both within and outside the country on an unprecedented scale. Many from all around the world were moved to pledge large sums

21 Keethaponcalan, supra note 19, at 414, 428.

22 For an insider's account of the peace process, see Austin Fernando, My Belly is White (2008) (Austin Fernando is the former Secretary of Defense). 
of money for reconstruction and rebuilding. Others were moved to visit and participate physically in the reconstruction and rebuilding process. Governments from all parts of the world also responded magnificently with generous pledges of humanitarian aid and other assistance.

At the time the tsunami struck, there was some apprehension that the ceasefire would not hold much longer. Soon after the tsunami hit, and in the light of the destruction caused to the Northern and Eastern regions of the country, some foresaw that the wave of destruction had opened a window of opportunity to revive and nourish a stagnant peace process. It provided an opportunity to look at the creation of new arrangements in relation to post-tsunami rebuilding and reconstruction in the hope that these initial arrangements would metamorphose into something more permanent for the North and East. However, this did not materialize as anticipated.

The LTTE and the government began discussions on a joint posttsunami aid mechanism but this process was shattered by the assassination of a senior LTTE leader in February 2005. Negotiations resumed through the facilitation of the Norwegian Government, and then in late June 2005, the Sri Lankan Government and the LTTE signed the Post Tsunami Operational Management Structure (P-TOMS) Agreement. ${ }^{23}$ This agreement envisaged the establishment of a three-tiered system that would involve the government, the LTTE and the Muslims in the supervision and implementation of post-tsunami rebuilding activities. It was the first time that the LTTE had entered into an agreement with the government on a matter pertaining to governance.

The P-TOMS Agreement drew considerable criticism from most sections of the Muslim community. Muslims, especially those in the Eastern coastal regions, suffered significantly as a result of the tsunami and the Muslims were angered because of their exclusion from the process of negotiations and also because of the role that was assigned to them in the PTOMS structure. The agreement was challenged by members of the Janatha

23 Keethaponcalan, supra note 19, at 461. 
Vimukthi Peramuna (JVP) before the Supreme Court and the Court stayed parts of the agreement in an Interim Order given in July $2005 .^{24}$

\section{POST-WAR DEVELOPMENTS}

\section{a. The Eighteenth Amendment of the Constitution}

The end of the ethnic war provided a huge window of opportunity to seek ethnic accommodation through a power sharing mechanism and to initiate a process of reconciliation for the three main ethnic groups - Sinhalese, Tamils and Muslims - devastated and traumatized by 30 years of conflict. Instead, what one saw a little over a year after the war ended, was a constitutional amendment that enhanced the powers of an already strong President and undermined the credibility of the country's independent institutions.

At the end of August 2010, the government suddenly announced that it was proposing to introduce the Eighteenth Amendment of the Constitution which was to make radical changes to the scheme of the Seventeenth Amendment. The Eighteenth Amendment was endorsed by the President and Cabinet of Ministers as an "urgent bill" on August 30, 2010 and sent for review to the Supreme Court on August 31, 2010.

On September 1, 2010, six petitioners argued that the Bill violated entrenched provisions of the Constitution and required the approval of the people at a referendum apart from the two thirds majority in Parliament. In an opinion communicated to the Speaker of Parliament the Supreme Court held that the amendment did not require a referendum and could be passed with the two thirds majority. ${ }^{25}$

The Eighteenth Amendment was passed by Parliament on September 8, 2010 with the two-thirds majority. Although the ruling alliance did not secure the two-thirds majority at the April parliamentary elections, it managed to win over some members of the opposition, including support

24 Wimal Weerawansa v. Attorney Gen., Supreme Court of Sri Lanka Minutes of July 15, 2005 (Interim Order of the Court).

25 The Constitution of the Democratic Socialist Republic of SRi lanka [SRI LANKa Const.] Sep. 7, 1978 art. 120-24. 
from the Sri Lanka Muslim Congress that helped it to secure the required two-thirds majority.

The amendment restores the unfettered power that the President previously had to make appointments to key public institutions with little consultation. ${ }^{26}$ It also removed the two-term limit on the Presidency.

Prior to the Eighteenth Amendment, the President could hold office for a maximum of two six-year terms. The Eighteenth Amendment removed this restriction and allowed the President to hold office for as many terms as possible. While the Constitution gives the President sweeping powers, the two term limit guaranteed that an incumbent could hold office for a maximum of 12 years. It provided hope to those aspiring for political power that they could aspire to the Presidency within the framework of the Constitution and without resorting to extra-constitutional means. These guarantees have now been removed.

The Eighteenth Amendment also repealed the Seventeenth Amendment to the Constitution, passed unanimously by Parliament in October 2001. The Seventeenth Amendment had previously established the Constitutional Council that was one of the few fetters on the exercise of Executive power.

The Seventeenth Amendment has established a multi-partisan Constitutional Council that consisted of the Speaker (Chairperson), the Prime Minister (PM), the Leader of the Opposition, a nominee of the President, five persons nominated jointly by the PM and the Leader of the Opposition, and one person nominated by the majority of members who belonged to political parties other than the parties to which the PM or Opposition Leader belonged. The Seventeenth Amendment also sought to establish an independent Election Commission, National Police Commission, Public Service Commission and an Administrative Appeals Tribunal, and to enhance the independence of the Judicial Service Commission. ${ }^{27}$

The Constitutional Council was responsible for approving or recommending appointments to several of the independent institutions in the country including the Human Rights Commission, the Police Commission, the Election Commission, the Supreme Court, Court of Appeal, and the Attorney General. The Seventeenth Amendment took away the unbridled

26 See discussion on the $17^{\text {th }}$ Amendment to the Constitution below.

27 SRI LANKa Const. amend. XVII (certified 2001). 
power that the President previously had with regard to the making of these key public appointments. Since then several statutes also integrated the Constitutional Council into their schemes of appointments. For example, the three appointments by the President to the Monetary Board of the Central Bank must now be made with the concurrence of the Constitutional Council. ${ }^{28}$ Appointments to the Public Utilities Commission must be made by the Minister with the concurrence of the Constitutional Council. ${ }^{29}$ Appointments to the Welfare Benefits Board must be made by the Minister in consultation with the Constitutional Council. ${ }^{30}$

The Constitutional Council became defunct in 2005 when the terms of six of its members expired. ${ }^{31}$ For about two years, minority parties in Parliament could not agree on who their nominee to the Constitutional Council would be. Yet even once this was resolved in January 2008, the President refused to make the appointments and constitute the Constitutional Council.

In July 2006, the government set up a Parliamentary Select Committee to review the Seventeenth Amendment and suggested reforms, and in March 2008, the Prime Minister stated the President would not constitute the Constitutional Council until he received the Select Committee Report. After nine meetings, the Committee submitted an interim report recommending certain amendments to the 17 th Amendment. ${ }^{32}$

In the meantime, the President continued to make appointments to key public positions, including the courts and the independent commissions, in a violation of the explicit constitutional provisions that such appointments

28 Monetary Law (Amendment) Act (Act No. 32/2002) §3(c) (Sri Lanka).

29 Public Utilities Commission of Sri Lanka Act (Act No. 35/2002) § 3(1).

30 Welfare Benefits Act (Act No.24/2002) § 4(2) (Sri Lanka).

31 For a more detailed discussion of these developments, see Transparency InT'L Sri Lanka, The Forgotten Constitutional Council: An Analysis of the Consequences of the Non Implementation of the 17Th Amendment (2008), available at http://www.tisrilanka.org/?p=229; Cyrene Siriwardena, Public Institutions and de-politicization: Rise and the fall of the 17th Amendment, in SRI Lanka State of Human Rights 2007, Law \& Society Trust 237-61 (2008).

32 Interim Report of the Select Committee of Parliament on the $17^{\text {th }}$ Amendment to the Constitution, 18 Law \& Society Trust Review 1 (2007). 
could be made only after receiving recommendations or the approval of the Constitutional Council. ${ }^{33}$

While the President refused to appoint members to the Constitutional Council, the Cabinet of Ministers transferred the functions and powers of the National Police Commission to the Inspector General of Police, and the powers of the Public Service Commission to the Secretaries of Ministries and Heads of Departments. ${ }^{34}$

Under the Eighteenth Amendment, the Constitutional Council has been replaced by an ineffective Parliamentary Council that consists entirely of members of Parliament. The President is required to seek the observations of the Parliamentary Council but is not obliged to follow those observations. The unbridled power that the President previously had in the making of key public appointments has been restored.

\section{b. The Presidency}

These Constitutional changes have to be assessed in the light of an ultrastrong Executive President that wields enormous powers. The Presidency has been the single most dominant factor affecting the exercise of power in Sri Lanka. It has allowed for the exercise of vast amounts of political power with very little accountability. ${ }^{35}$

The President is the Head of State, Head of the Executive and the Government, and the Commander in Chief of the Armed Forces. ${ }^{36}$ The President is elected directly by the people for a fixed term of six years and is not a member of the Legislature. ${ }^{37}$ As a result of a subsequent constitutional amendment, the President may call for an election after four years, at his or her discretion.

The current Constitution enables the President to assume any Ministerial responsibility, including that of Finance, and appoint members of the cabinet with no obligation to consult with the Prime Minister or the

33 See Transparency Int'L, supra note 30.

$34 \quad I d$.

35 See Joseph A. L. Cooray, Constitutional and Administrative Law of Sri Lanka (1995); A. Jeyaratnam Wilson, The Gaullist System in Asia: The Constitution of SRi Lanka (1978) (1980).

36 SRi Lanka Const. art. 30.

37 Id. at art. 30(2). 
Legislature on these appointments. ${ }^{38} \mathrm{He}$ or she is immune from judicial review while he or she is in the office and has the power to dissolve a democratically elected legislature without assigning reasons; in some cases after the legislature has completed one year in the office and in other cases even within the first year. ${ }^{39}$ In 2003, the then President assumed three crucial ministries, dissolved what was a democratically elected legislature without assigning any reason, and called a fresh election in April 2004.

The President may also declare an emergency and govern by way of emergency regulations with little judicial oversight. ${ }^{40}$ A small fetter on the President's power was the Constitutional Council introduced by the Seventeenth Amendment to the Constitution in 2001, which has now been repealed.

The vast powers reposed in the office of the President has enabled the office holder to influence many of the independent institutions that are responsible for protecting and promoting human rights, including the judiciary, the Attorney General, and the Human Rights Commission. Soon after the April 2010 Parliamentary election, the Attorney General was brought directly under the purview of the President. Ensuring a more equitable balance of power among the three organs of the government the Executive, the Legislature and the Judiciary - is a priority if effective institutions are to emerge in Sri Lanka.

\section{c. Withdrawal of GSP Plus Concessions}

In August 2010, the European Union suspended the GSP Plus trade concession to Sri Lanka. According to the E.U., there were significant shortcomings in the way Sri Lanka was implementing three core U.N. human rights treaties which entitled it to the special tariff concession.

The E.U.'s GSP Plus concession enabled developing countries to export to E.U. markets under a reduced tariffs rate so long as they conformed to certain governance and human rights standards. Sri Lanka applied for and was granted the GSP Plus benefits in 2005. At that time the country stated

38 Id. at art. 44-6.

39 Id. at art. 70.

40 See Sri LANka Const. art. 154(J)(2), according to which a proclamation of emergency by the President under the Public Security Ordinance cannot be challenged in a court of law. 
that it had ratified and was effectively implementing 16 core human rights and labor conventions ${ }^{41}{ }^{4}$ In 2008, the country sought continuation of the GSP Plus benefits stating that there was tangible progress in complying with the relevant conventions.

According to the government, exports to EU markets grew by $42 \%$ over a five-year period as a result of the GSP Plus concession. The apparel industry, which provided direct employment to about 270,000 and indirect employment to a further one million, benefitted in particular. ${ }^{42}$

In October 2008, the EU decided to initiate an investigation to ascertain whether the International Covenant on Civil and Political Rights (ICCPR), the Convention against Torture and other Cruel, Inhuman or Degrading Treatment or Punishment (CAT) and the Convention on the Rights of the Child (CRC) were being effectively implemented in Sri Lanka. The E.U. appointed three independent experts to assist the investigation. ${ }^{43}$ The government of Sri Lanka refused to participate in the investigation.

After a review of the report submitted by the three independent experts, a review of U.N. and other documents, the E.U. concluded in October 2009 that there were significant shortcomings in the way the three conventions (ICCPR, CAT and CRC) were being implemented. In February 2010, it announced that it was suspending the GSP Plus concessions with effect from August 15, 2010.

Subsequently, the E.U. identified 15 measures to enable a six-month extension of the GSP Plus concession. These included a recommendation to

41 Commission of the European Communities, Report on the Findings of the Investigation with Respect to the Effective Implementation of Certain Human Rights Conventions in Sri Lanka (2009), reprinted in 20 LaW \& Society Trust Review 4 (2010).

42 See Government of Sri Lanka, The Observations of the Government of SRi LANKA In RESPeCt OF THE "Report ON The Findings of the Investigation with Respect to the Effective Implementation of Certain Human Rights Conventions in Sri Lanka" (2009), reprinted in 20 Law \& Society Trust Review (2010).

43 See Interim Report by an Expert Committee of the European Union in Respect of Renewal of the Special Incentive Arrangement for Sustainable Development and Good Governance (GSP+), Aug. 19, 2009, The Implementation of Certain Human Rights Conventions in Sri Lanka (2009), reprinted in 20 Law \& Society Trust Review (2010). 
repeal or modify the Emergency Regulations and the PTA (Prevention of Terrorism Act) to bring them in line with the ICCPR; to permit the ICRC to monitor the conditions of detainees; to inform the family members of detainees of their whereabouts and to release them or bring them to trial; to ensure that appointment to key institutions are in accordance with the Seventeenth Amendment; and to extend invitations to the U.N. Special Procedures that had sought permission to visit.

The government, however, did not find these recommendations acceptable. In the face of the government's intransigence, its unwillingness to engage in a genuine dialogue and its unwillingness to make even some basic changes, the EU was forced to withdraw the concessions despite the consequences it may have on the employees of the various industries that were exporting to the E.U.

\section{d. The Trial of the Former Army Commander}

Sarath Fonseka was the Commander of the Sri Lanka Army at the time the state unleashed its final assault on the LTTE in 2008 and 2009. He escaped an LTTE suicide assassination attempt in April 2006.

Soon after the war against the LTTE ended in May 2009, Fonseka was appointed as the Chief of Defense Staff, a largely ceremonial position with little real power. This was done to prevent the possibility of an army takeover in the public euphoria following the elimination of the LTTE and the killing of its leadership.

Fonseka then resigned from the army and decided to contest the incumbent President at the January 2010 poll as the candidate from the Opposition alliance. For the Opposition, the only way they could have matched the soaring popularity of a President (who had ended the war) was to field another "war hero" in the form of General Fonseka. Despite Fonseka's popularity as the general who led the war, President Rajapakse won the election comfortably and took office for the second term.

Fonseka's decision to contest the President was viewed as an act of betrayal by the regime and Fonseka was made to pay heavily for this. After he lost the contest for the Presidency, Fonseka contested the Parliamentary elections in April 2010 and was elected as a Member of Parliament. The President then constituted a court martial under the Army Act to try 
Fonseka on several counts while he was holding office as Commander of the Army.

On September 17, 2010, the Court Martial convicted General Fonseka, stripped him of his rank and sentenced him to an aggregate of 30 months imprisonment. The conviction and sentence was confirmed by the President on September 29, 2010, as he was required to do. In this case, the court martial was established by the President, the members were appointed by the President, and the conviction and sentence were affirmed by President, as required by the Army Act. ${ }^{44}$ As a result of his conviction, Fonseka lost his Parliamentary seat. Imprisonment for a period in excess of six months disqualifies a person from being elected as a Member of Parliament. ${ }^{45}$

Fonseka challenged his expulsion from Parliament before the Supreme Court. One of the issues before the court was whether a Court Martial was a "court" in terms of the constitutional provisions. Five judge benches of the Supreme Court held that it was and affirmed the conviction of Fonseka. ${ }^{46}$

From Constitutional perspective, expulsion of members of the legislature must be done after observing all the guarantees of due process and a fair trial. Where the Executive initiates a process of expulsion and interferes with the trial, there is an obvious violation of the separation of power. The initiation of the process of disqualification by the Executive would also constitute a violation of the franchise which is vested in the people according to the Constitution. ${ }^{47}$

One of the consequences of this process has been that the only serious political contender to the incumbent President (because of his participation in the war against the LTTE) has now been marginalized and incarcerated through a process that has taken place within the formal confines of the law. It is a process that has received the stamp of approval from the Supreme

\footnotetext{
44 Army Act (Act No. 17/1949) (Sri Lanka).

45 SRi LANKa Const. art. 89(d).

46 Gardihewa Sarath Fonseka v. Dhammika Kithulegoda, Supreme Court Minutes of Sri Lanka of January 10, 2011.

47 See SRi Lanka Const. art. 4(e).
} 
Court. In May 2012, Fonseka received a pardon from the President and was released from prison.

\section{e. The U.N.'s Accountability Panel}

On June 22, 2010, Secretary General Ban Ki-moon appointed a three-member panel to advise him on violations of human rights and humanitarian law that occurred during the final stages of the conflict. The Panel consisted of Marzuki Darusman (Indonesia), Steven Ratner (USA) and Yasmin Sooka (South Africa), and the Panel commenced its work on September 16, 2010.

According to the U.N., the panel was established in accordance with the agreement that the Secretary General reached with the President during his visit to the country in May 2009, soon after the end of the war. At the end of his visit, the Secretary General and President issued a joint statement in which the President of Sri Lanka agreed to address accountability issues in relation to the violation of international humanitarian law and human rights law during the final stages of the conflict. According to the Secretary General, addressing accountability was an essential foundation for durable peace and reconciliation in the country and the Panel of Experts was appointed as a follow up to this joint statement. The report of the Panel of Experts was released in April 2011. ${ }^{48}$

The government tried to prevent the appointment of the U.N. panel by constituting a "Lessons Learnt and Reconciliation Commission" under the Commissions of Inquiry Act in May 2010. The LLRC, however, was asked to inquire into events only between 2002 and 2009 and was given a narrow and ambiguous mandate.

The government's version of the last stages of the war was that it pursued a humanitarian operation with the aim of implementing a policy of "zero civilian casualties." According to the Panel of Experts, however, there were credible allegations, which if proven, show that there were a range of serious violations of international humanitarian law and human rights law committed by both the Government of Sri Lanka and the LTTE, some of which would amount to war crimes and crimes against humanity. According to the Panel, the conduct of the war "represented a grave assault

48 U.N. Secretary-General, Report of the Secretary-General's Panel of Experts on Accountability in Sri Lanka, (Mar. 31, 2011), http://www.un.org/News/dh/infocus/ Sri_Lanka/POE_Report_Full.pdf. 
on the entire regime of international law designed to protect individual dignity during both war and peace." ${ }^{.49}$

The Panel noted that the government repeatedly shelled three "No Fire Zones" in which it had asked civilians to congregate and repeatedly shelled hospitals on the frontlines. The Panel also found that there were credible allegations that the LTTE had fired at civilians attempting to flee their control, used civilians as a buffer, recruited children, and used military equipment in the proximity of civilians.

The Panel's report generated hostile reactions from the government, some sections of the media and the political Opposition, and the government engaged in a major diplomatic offensive with a focus on China, Russia and members of the Non-Aligned Movement in an effort to prevent further action by the U.N.

The Panel was appointed to advise the Secretary General on the measures he should take to address accountability. Without authorization from the Security Council, General Assembly or the Human Rights Council, it is unlikely that the Secretary General could take steps to implement the recommendations of the report.

\section{f. The Lessons Learnt and Reconciliation Commission}

The government tried to prevent the appointment of the U.N. panel by constituting a "Lessons Learnt and Reconciliation Commission" under the Commissions of Inquiry Act in May 2010. The LLRC was given a narrow and ambiguous mandate and asked to inquire into events only between 2002 and 2009. The establishment of the LLRC was viewed with skepticism and the independence of some of its members was questioned. ${ }^{50}$

Despite the narrowness of its mandate and the initial reservations that many had, the LLRC issued a report in November 2011 with a broad range of recommendations for reconciliation and institutional reforms. ${ }^{51}$ As the LLRC observed:

the root cause of the ethnic conflict in Sri Lanka lies in the failure of successive Governments to address the genuine grievances of

\footnotetext{
49 Id. at ii.

50 See Int'l Crisis Grp., Reconciliation in Sri Lanka: Harder than Ever, Asia REPORT No. 209, 22-6 (2011).

$51 \quad$ LLRC Report, supra note 12.
} 
the Tamil people. The country may not have been confronted with a violent separatist agenda, if the political consensus at the time of independence had been sustained and if policies had been implemented to build up and strengthen the confidence of the minorities around the system which had gained a reasonable measure of acceptance. ${ }^{52}$

A political solution is imperative to address the causes of the conflict. Everybody speaks about it, though there is no agreement about the diagnosis and the prescription. It is a process that is ongoing at the moment. At such a moment it is most opportune to look back at what is not so long a period of history of Sri Lanka as an independent country. ... and some commentators even remarked that after 63 years of independence the country is, in some ways, back at square one. ${ }^{53}$

The LLRC concluded however, that there was no deliberate targeting of civilians during the large stages of the war although it recommended that specific events be further investigated.

\section{g. The Human Rights Council Resolution}

In March 2012, the U.N. Human Rights Council adopted a resolution on Sri Lanka. This was the first resolution against Sri Lanka by the new Human Rights Council, a similar resolution in May 2009, soon after the war ended, having been defeated.

The U.S sponsored resolution welcomed the recommendations contained in the LLRC's report

... including the need to credibly investigate widespread allegations of extrajudicial killings and enforced disappearances, demilitarize the north of Sri Lanka, implement impartial land dispute resolution mechanisms, re-evaluate detention policies, strengthen formerly independent civil institutions, reach a political settlement on the devolution of power to the provinces, promote and protect the right of freedom of expression for all and enact rule of law reforms. ${ }^{54}$

The resolution called upon the government to "implement effectively the constructive recommendations made in the report of the Lessons Learnt

52 Id. at 291.

53 LLRC Report, supra note 12, at 291.

54 U.N. Human Rights Council, Promoting Reconciliation and Accountability in 
and Reconciliation Commission, and to take all necessary additional steps to fulfill its relevant legal obligations and commitment to initiate credible and independent actions to ensure justice, equity, accountability and reconciliation for all Sri Lankans." ${ }^{55}$ The resolution asked the government to present "a comprehensive action plan detailing the steps that the Government has taken and will take to implement the recommendations made in the Commission's report, and also to address alleged violations of international law." ${ }^{\prime 6}$ The government engaged in a major diplomatic initiative to prevent the adoption of the resolution, but did not succeed. India was among those countries that supported the resolution.

One of the country's most respected diplomats, now retired, writing after the event called it the "Death of Sri Lankan diplomacy by suicide!"57 According to Dhanapala, "domestically, the Geneva resolution might help to ensure the re-election of the President; but internationally, it may destabilize the entire country, dragging us all into a dystopia that our people do not deserve." ${ }^{58}$

\section{IMPUNITY IN SRI LANKA}

\section{a. Post-Conflict Justice}

Impunity has been one of the major human rights issues over the past thirty years. Despite several hundred extra judicial killings, abductions, suicide bombings, claymore mine attacks, torture and other acts of violence and intimidation, few of the perpetrators have been made accountable for their

Sri Lanka, U.N. Doc. A/HRC/19/L.2 (Mar. 22, 2012).

55 Id.

$56 \quad I d$.

57 Jayantha Dhanapala, The Death of Sri Lankan Diplomacy by Suicide, LANKA Monthly Digest, (May, 2012), http://www.LMD.lk, as reprinted in The NATion, May 20, 2012, http://www.nation.lk/edition/news-features/item/6259-death-ofsri-lankan-diplomacy-by-suicide.html.

$58 \quad I d$. 
crimes. ${ }^{59}$ Both the state and non-state actors have been guilty of human rights violations and violations of international humanitarian law.

The state has been reluctant to use the criminal law to pinpoint accountability and formal court processes have been employed only on limited occasions. So far prosecutions have been initiated and sustained only in a handful of cases. Three of the most high profile of these cases was the Krishanthi Kumaraswamy case,${ }^{60}$ the Embilipitiya massacre,${ }^{61}$ and the Bindunuwewa massacre. ${ }^{62}$ In the Bindunuwewa case, the conviction was overturned in appeal. ${ }^{63}$ As an eminent human rights scholar observes "a once respected legal and institutional system that upheld the rule of law has over some three decades been degraded into one characterized by pervasive immunity." ${ }^{64}$

Rather than using the regular justice system, the state has instead chosen to rely on a variety of ad hoc commissions, most of which have had little or no impact. ${ }^{65}$ The Commission of Inquiry Act, under which

59 See Mario Gomez, Sri Lanka: Case Study on Post-Conflict Justice, in 2 The Pursuit of International Criminal Justice: A World Study on Conflicts, Victimization, and Post-Conflict Justice 763-84 (M. Cherif Bassiouni ed., 2010).

60 The Krishanthi Kumaraswamy Case, (1998) High Ct. Decision of July 3, 1998-(Sri Lanka). See also Shyamala Gomez \& Mario Gomez, Gender Violence in Sri Lanka: From Rights and Shame to Remedies and Change 102-03 (1999).

61 State v. Dayananda Lokugalappathi and others, (2002) High Ct. 121 of 1994, conviction on Feb. 10, 1999 (Sri Lanka).

62 The Bindunuwewa Case, Hign Ct. (2002) 763 of 2002 (Sri Lanka). See also Alan Keenan, Bindunuwewa: Justice Undone?, in Sri Lanka: State of Human Rights 2004, LaW \& Society Trust 185-242 (2004); Alan Keenan, Making Sense of Bindunuwewa - From Massacre to Acquittals, 15 LaW \& Societr Trust Review (2005).

63 Sammy v. Attorney Gen., Supreme Court of Sri Lanka Minutes of May 27, 2005, reprinted in 15 Law \& Society Trust Review (2005).

64 Nigel Rodley, quoted in Kishali Pinto-Jayawardena, Still Seeking Justice in Sri Lanka: Rule of Law, the Criminal Justice System and Commissions of Inquiry since 1977 vii International Commission of Jurists (2010).

65 See Amnesty International, Twenty Years of Make-Believe: Sri Lanka's Commissions of Inquiry (2009); Kishali Pinto-Jayawardena, Still Seeking Justice in Sri Lanka: Rule of Law, the Criminal Justice System and Commissions of Inquiry since 1977, 
most of these commissions have been established, gives the Executive the power to determine the scope of the inquiry, select the commissioners, control its finances, and order termination of the inquiry with no reasons having to be provided. There is no obligation on the Executive to ensure the publication of commission reports.

By and large, there has been no accountability for serious human rights violations and impunity has been allowed to flourish. ${ }^{66}$ Some of the commissions of inquiry found evidence of the systematic use of violence by state officers and recommended prosecution. Despite these findings, few prosecutions were initiated and fewer sustained. In majority of the cases, there have been no investigations. Survivors of some victims have received compensation and other government assistance as a result of the

International Commission of Jurists (2010); Kishali Pinto-Jayawardena, A Legacy to Remember: SRI LANKA's Commissions of INQUiry, 1963-2002 (2010).

66 See also Special Rapporteur on Extrajudicial, Summary or Arbitrary Executions, Mission to Sri Lanka, U.N. Doc. E/CN.4/2006/53/Add.5 (Mar. 27, 2006) (by Philip Alston); Special Rapporteur on Extrajudicial, Summary or Arbitrary Executions, Follow-up to Country Recommendations, U.N. Doc. A/HRC/8/3/Add.3 (May 14, 2008) (by Philip Alston); Colombo, Sri Lanka: Press Statement by the U.N. High Comm'r for Human Rights on the Conclusion of Her Visit to Sri Lanka, Asian Human Rights Commission, Oct. 13, 2007; Special Rapporteur on Torture and Other Cruel, Inhuman or Degrading Treatment or Punishment, Mission to Sri Lanka, U.N. Doc. A/HRC/7/3/Add6 (Feb. 26, 2008) (by Manfred Nowak); U.N. Human Rights, Office of the High Comm'r for Human Rights, Joint Civil Society Report for Universal Periodic Review of Sri Lanka to the U.N. Human Rights Council (May, 2008), http://www.ohchr.org/EN/HRBodies/UPR/Pages/ UPRLKStakeholdersInfoS2.aspx; U.N. Human Rights, Office of the High Comm'r for Human Rights, UN Experts Concerned at Suppression of Criticism, Impunity, (Feb. 9, 2009) (quoting the views of 10 independent U.N. experts and special rapporteurs); Statement by Ms. Magdalena Sepulveda, Independent Expert on Human Rights and Extreme Poverty, delivered on behalf of all Special Procedures of the Human Rights Council at the Eleventh Special Session of the U.N. Human Rights Council on the Human Rights Situation in Sri Lanka in Press Release, Human Rights Council, Human Rights Council Opens Eleventh Special Session on Situation of Human Rights in Sri Lanka (May 29, 2009); Univ. Teachers for Human Rights, A Marred Victory and a Defeat Pregnant with Foreboding (2009); See Kishali Pinto-Jayawardena, supra note 64; International Crisis Group, supra note 2, at 27-30. 
findings of some of the ad hoc commissions of inquiry. Memorials have been built in a few cases.

At the moment, it is highly unlikely that the state will pursue any process of accountability with regard to serious human rights violations committed in the past. There may be some prosecutions of LTTE cadres, but there will certainly be no prosecution against state officials. There is also unlikely to be any form of truth seeking that will enable victims from all communities to place their stories before an official panel and create a historical record of the conflict.

Article 12 of the Sri Lankan Constitution guarantees the right to equality before the law and the right to equal protection of the law. Article 4(d) of the Constitution obliges all organs of government to respect, secure and advance the fundamental rights recognized by the Constitution. Despite these clear constitutional guarantees and the international obligations that the country has taken on, there is unlikely to be any accountability for human rights violations committed by the state in the recent past. A change of regime may provide a small window of opportunity for holding perpetrators responsible. But this is unlikely to occur in the near future, and even if it does occur, it will need to be made use of quickly. ${ }^{67}$

\section{b. A Crisis of Institutions}

Sri Lanka has witnessed a progressive decline in the independence and effectiveness of most of its democratic institutions over these past forty years. These include the police, the public service, the Parliamentary Oversight Committees, the Attorney General's Department, the judiciary, the Public Service Commission, the Human Rights Commission, the Police Commission, and the Commission to Investigate All Forms of Bribery or Corruption (CIABOC). At the moment there is no national institution that

67 "Regime change" has historically provided an opportunity for positive change. However, regimes tend to be more open to change at the beginning of their tenure and tend to adopt more confrontational positions as they become more secure in power. 
commands the credibility and respect of all sections of Sri Lankan society and of all its communities. ${ }^{6}$

In 2007, the High Commissioner for Human Rights Louise Arbour, observed that "people from across a broad political spectrum and from various communities have expressed to me a lack of confidence and trust in the ability of existing relevant institutions to adequately safeguard against the most serious human rights abuses." 69

The concentration of power, first in a supreme Parliament in the seventies, followed by a concentration of power in a strong executive Presidency since 1978, has affected all of the country's institutions in a profoundly negative way. As a result of this concentration of power, Sri Lankan institutions have been rendered ineffective for the most part through politicization or dominance by the Executive. ${ }^{70}$

\section{TRANSITING FROM WAR TO THE RULE OF LAW}

\section{a. The Challenges of Transition}

Sri Lanka post-war experiences are different to many other post-war societies in two ways. First, the war ended without a negotiated peace agreement and with a clear victor: the Sri Lankan state. Second, there have been no major constitutional, institutional or other changes to accommodate and respond to the root causes of the war. The only major constitutional

68 See also Int'l Bar Ass'N, supra note 4; INT'L Crisis GrP., SRI LANKA's JUdiciary: Politicized Courts, Compromised Rights, Asia Report No. 172 (2009); Transparency Int'L Sri Lanka, National Integrity System Assessment: Sri Lanka 2010 (2011); Basil Fernando, Recovering the Authority of Public Institutions: A Resource Book on Law and Human Rights in Sri Lanka (2009).

69 Statement of Louis Arbour, High Commissioner for Human Rights (Oct. 13, 2007).

70 See also Transparency Int'L Sri Lanka, Sri Lanka: Governance Report (2008); Transparency Int'l SRi Lanka, supra note 4; LaW \& Society Trust, SRi Lanka: State of Human Rights 2007, 237-61 (2007). 
change that occurred was aimed at consolidating the regime's hold on political power.

The post-war situation in many countries provides a unique opportunity to investigate past human rights violations and prosecute serious violators; initiate a process of reparations, reconciliation and healing; engage in institutional re-building and reform; and probe the causes that gave rise to the conflict. In many post-war societies, pressures from external actors and pressures from victims and civil society within the country have forced the political regime to engage in a search for accountability and in institutional reform. The U.N. intervened in the former Yugoslavia, Rwanda, Sierra Leone, Timor and Cambodia. The situations in the Democratic Republic of Congo, the Central African Republic, Northern Uganda and Kenya are now before the International Criminal Court. In South Africa pressures from within ensured that reconciliation and accountability were not ignored in a post-apartheid society. ${ }^{71}$

Sadly, this has not been the case in Sri Lanka. The political regime has steadfastly refused to deal with issues of accountability or address questions of power sharing and has resisted external governments and entities that have raised these issues. One of the longstanding demands from Tamil political actors has been the demand for a power sharing agreement that will enable Tamils in North and East to exercise some degree of control over those geographical areas. The government's failure in the past to respond to these demands led to the civil war and a reluctance to respond yet again risks another cycle of violence.

\section{b. Real Reconciliation}

The ending of a nearly three decades of protracted and bloody conflict has opened many opportunities for bringing about reconciliation between the different communities, especially among the Sinhalese, Tamils and the Muslims... .Acknowledging the losses and suffering of the past and providing mechanisms for recompense, social justice and for restoration of normalcy and expressions of empathy and solidarity, are steps aimed at redress. Relationship - building following violent conflict, addressing issues of lack of

71 M. Cherif Bassiouni ed., supra note 58. 
trust, prejudice, and intolerance whilst accepting commonalities and differences, is the essence of reconciliation. ${ }^{72}$

People from all corners of the country who came before the Commission left with the Commission an almost palpable impression that this is Sri Lanka's moment of opportunity for Sri Lankans to collectively chart a vision for a harmonious future for our nation and a wholesome Sri Lankan identity. ${ }^{73}$

Most Sri Lankans are basking in a peace that the end of the war has brought. The sense of fear that previously prevailed has been lifted and optimism has begun to grow. For many other people however, especially those living in the North and East, and those whose lives were closely entwined in the conflict, life continues to be problematic. While the direct violence has stopped, some of them still live in fear and others in a sense of insecurity. The military presence, especially in the North, remains strong, many still pine for and seek information on the fate of family and friends and there is a fear of a deliberate alteration of the ethnic balances in the North and East. Transparency and participation remain a big concern. The government has embarked on a major development drive to re-build damaged areas, build new infrastructure, and promote tourism and investment. Yet much of this policy is tightly controlled. There is little transparency and little consultation with stakeholders.

The end of the war three year ago has provided Sri Lanka with a unique opportunity to build a plural and democratic society wedded to human rights and the rule of law. It has provided an opportunity to forge a national consensus on major social and political issues, pursue equitable and sustainable economic growth and enhance the country's social capital.

Yet developments over the past three years indicate otherwise. The current regime's unwillingness to address the issues that led to the violence; the unwillingness of the regime to be transparent and to engage in widespread consultation on reconciliation and economic policy among other things; and the sense of unease and sometimes fear that prevails in some parts of the country, hover like a dark cloud. Sri Lankans have missed several previous opportunities to forge a sustainable peace. ${ }^{74}$ This is perhaps the

\footnotetext{
72 LLRC Report, supra note 12, at 8.136.

73 Id. at 8.140 .

74 Ketheshwaran Loganathan, supra note 18; John Richardson, Paradise Poisoned: Learning about Conflict, Terrorism, and Development from
} 
best opportunity the country has had in the recent past, and yet there is a sense of unease that this opportunity may also be squandered.

The end of the violence is a necessary first step in the process of transforming the Sri Lankan conflict. In Sri Lanka the direct violence has ceased, not through a negotiated settlement or a military stalemate, but through a decisive military victory. Moving from here to a place where differences are reconciled peacefully, where the voices of all social groups are heard, and where equality, equity and transparency will form fundamental principles of governance, is the more challenging next step.

Many other societies that have moved from war to peace, or from dictatorship to democracy, have been forced to negotiate political compromises and put in place new constitutional and institutional arrangements. Some have even dealt with the past. Not so in Sri Lanka. The state's decisive military victory has enabled it to craft its own agenda. One would have expected a political regime basking in the afterglow of victory to seek reconciliation and deal with some of the political issues that gave rise to the violence. This has not happened. Instead there has been a move towards a further consolidation of power in the ruling regime and a reluctance to tolerate dissent. The LLRC has noted in its report:

From the representations made to the Commission it has formed the distinct impression that the problem is far from solved. There is a sense of unhappiness among the minorities that the State had neglected its responsibility towards them. Since it is a political problem, it needs to be addressed politically. It is necessary to address the root causes of the conflict. It is the primary duty of the State to be proactive and the citizenry should respond in a spirit of give-and-take. ${ }^{75}$

The Commission was also reminded that despite the lapse of two years since the ending of the conflict, the violence, suspicion and sense of discrimination are still prevalent in social and political

SRI LANKA's Civil WARS (2007).

75 LLRC Report, supra note 12, at 8.141. 
life. Delay in the implementation of a clearly focused post conflict peace building agenda may have contributed to this situation. ${ }^{76}$

\section{c. Sustaining the Peace}

Reach out to those you fear

Touch the heart of complexity

Imagine beyond what is seen

Risk vulnerability one step at a time

John Paul Lederach ${ }^{77}$

Forging a sustainable peace will at a minimum, require the following:

\section{CONSTITUTIONAL AND INSTITUTIONAL REFORM}

A new Constitution, drafted with the participation of all ethnic and social groups, will need to incorporate an effective scheme for the sharing of power among local government areas, the regions and the center. ${ }^{78}$ The powers to be exercised by each sphere of government should be defined precisely and should not be capable of modification without the consent of the regions. ${ }^{79}$

The Executive Presidency should either be abolished or amended and a more equitable balance of power must be established amongst the three organs of state: the Executive, the Legislature and the Judiciary. If the Presidency is amended, the President should not be permitted to hold any ministerial portfolio. The Cabinet of Ministers should consist entirely of

$76 \quad$ Id. at 8.147.

77 John Paul Lederach, The Moral Imagination: The Art and Soul of Building Peace (2005).

78 See Autonomy and Ethnicity: Negotiating Competing Claims in MultiETHnic States (Yash Ghai ed., 2000), for a discussion of how multi-ethnic states have addressed diversity and difference through constitutional and other arrangements.

79 See Edrisinha, Gomez, Thamilmaran and Welikala, Power Sharing in SRi Lanka: Constitutional and Political Documents, 1926 - 2008 (2008), for an analysis of previous attempts at power sharing; A NEW CONSTITUTIONAL Framework for Sri Lanka: Proposals from Business and Civil Society (Mario Gomez ed., 2007). 
Members of Parliament. The immunity provided to an incumbent President must be removed.

A constitutional right to access information that should be in the public domain must be guaranteed. This must be supported by the enactment of a Right to Information law that will spell out in detail the procedures for accessing public information. Such a law must be drafted in consultation with the media and civil society. ${ }^{80}$

\section{DEALING WITH THE PAST}

A Truth and Reconciliation Commission should be established. Such a Commission must be independent and be established under special legislation passed for this purpose. It must be empowered to probe human rights violations over the past 40 years; identify perpetrators; recommend sanctions or other appropriate action; recommend compensation and other reparations; and identify measures to promote reconciliation and healing among the different ethnic and social groups.

\section{A TRANSPARENT LAND POLICY}

Access to land was one of the drivers of the conflict and is a potential source of future conflict and violence. Land policy in a post-war environment must be based on transparent and principled criteria and administered by an independent institution. Displaced persons have a right to return to their places of origin and to have their housing, land and other property restored to them. Where restoration is not possible, as determined by an independent tribunal, then they have a right to adequate compensation or other reparations. ${ }^{81}$

\section{THE RIGHT TO DISSENT}

The right to free expression, publication and dissent must be respected and promoted. The killing, disappearance and abduction of journalists

80 Mario Gomez, Lifting the Veil of Secrecy: The Right to Information in Emerging and Existing Democracies 2012 (unpublished paper).

81 See The Pinheiro Principles: United Nations Principles on Housing and Property Restitution for Refugees and Displaced Persons, Ctr. on Hous. Rights AND Evictions (2005); U.N. Secretary-General, U.N. Guiding Principles on Internal Displacement, http://www.unhcr.org/43celcff2.html or U.N. Comm'n on Human 
must be investigated and the perpetrators brought to justice. State media institutions (radio, television and print) should be freed from state control. They should be run as public trusts and administered by an independent and impartial Board of Directors. The right of civil society to organize and function freely should be respected and promoted. The state should refrain from interfering in the work of civil society or humanitarian organizations.

\section{A LOST OPPORTUNITY?}

At one level ensuring a sustainable peace will require some fundamental constitutional, institutional and policy changes. At another level it will require a change in mindsets and magnanimity on the part of the state to reach out to all communities and social groups or, as Lederach calls it, the capacity to generate, mobilize and build the moral imagination. ${ }^{82}$ Political leadership has so far not shown the political will or the magnanimity to make and implement changes in a principled way that will create a win-win situation for different political elites and the country as a whole.

Sri Lanka has squandered many opportunities in the past. The events of the past three years suggest that this moment may also slip by.

Rights, Guiding Principles on Internal Displacement, U.N. Doc. E/CN.4/1998/53/ Add.2 (Feb. 11, 1998). See also Mario Gomez, Extinguishing Fear: The Challenge of Land Policy in Eastern Sri Lanka (2011).

82 For John Paul Lederach, transcending violence is forged by the capacity to generate, mobilize and build the moral imagination; See LEDERACH, supra note 76. 